\title{
Saccharomyces cerevisiae has an inducible response to menadione which differs from that to hydrogen peroxide
}

\author{
Jacinta Flattery-O'Brien, Lindsay P. Collinson and Ian W. Dawes* \\ School of Biochemistry and Molecular Genetics, University of New South Wales, PO Box 1, Kensington, \\ NSW 2033, Australia
}

(Received 17 August 1992; revised 20 October 1992; accepted 16 November 1992)

\begin{abstract}
Exponential phase cells of Saccharomyces cerevisiae treated with the superoxide free-radical generating agent menadione (MD; $0.2 \mathrm{mM}$ ) for $60 \mathrm{~min}$ adapted to become resistant to the lethal effects of a higher concentration of MD (4 mM). Inhibition of protein synthesis by treatment with cycloheximide totally prevented the adaptation to MD, indicating that this is an inducible response completely dependent on protein synthesis; this differs from the situation with peroxide in which only some of the adaptive response is cycloheximide-sensitive. Cells subjected to heat shock $\left(23\right.$ to $\left.37^{\circ} \mathrm{C}\right)$ or treatment with hydrogen peroxide $\left(\mathrm{H}_{2} \mathrm{O}_{2} ; 0.2 \mathrm{mM}, 60 \mathrm{~min}\right)$ became more resistant to $4 \mathrm{mM}-\mathrm{MD}$; however, MD pretreatment did not induce any thermotolerance or resistance to peroxide. These differences between the response to $\mathrm{MD}$ and $\mathrm{H}_{2} \mathrm{O}_{2}$ were reflected in the results of $\mathrm{L}-\left[{ }^{35}\right.$ S|methionine labelling studies. Using one-dimensional electrophoresis, only one polypeptide $(60 \mathrm{kDa})$ was seen to be induced by $0.2 \mathrm{mM}-$ MD and this was also induced by heat shock but not peroxide stress. With heat shock or peroxide treatment the induction of at least 10 polypeptides was detected using this approach. Using an isogenic petite strain, it was found that functional mitochondria were needed for conferring full resistance to MD, but that induction of the adaptive response was not dependent on mitochondrial function.
\end{abstract}

\section{Introduction}

The transfer of electrons to oxygen and its reduction to water is the final step in the respiratory chain. During this reaction, however, reactive oxygen species such as the superoxide anion, $\left(\mathrm{O}_{2}^{-}\right), \mathrm{H}_{2} \mathrm{O}_{2}$ and the hydroxyl radical $(\mathrm{OH} \cdot)$ are generated (Scandalios, 1990). These oxidants can cause widespread damage to the cell affecting nucleic acids, proteins and lipids (Storz et al., 1987; Dean \& Simpson, 1989). Macrophages and neutrophils use these destructive properties to their advantage by releasing superoxides and $\mathrm{H}_{2} \mathrm{O}_{2}$ as part of the immune response (Andrew et al., 1985). Not surprisingly, therefore, in order to prevent self-destruction and to protect against oxidant attack, mechanisms have evolved which inactivate these reactive species. Such mechanisms include production of detoxifying enzymes such as superoxide dismutase and catalase, as well as synthesis of protective molecules including glutathione, ascorbic acid and uric acid (Phillips \& Hilliker, 1990).

\footnotetext{
*Author for correspondence. Tel. (02) 697 2089; fax (02) 3136271.

Abbreviation: MD, Menadione (2-methyl-1,4-napthoquinone).
}

Studies on the effects of reactive oxygen species in prokaryotes, especially Escherichia coli and Salmonella typhimurium, have revealed much about the response of these organisms to oxidative stress. Demple \& Halbrook (1983) showed that the response to $\mathrm{H}_{2} \mathrm{O}_{2}$ stress was inducible, and Christman et al. (1985) found that approximately 30 proteins are synthesized during this response, nine of which are regulated at the level of transcription by a positive regulator, $\operatorname{oxy} R$. The $E$. coli locus sox $R$ controls the synthesis of nine of about 40 proteins induced by superoxide stress (Tsaneva \& Weiss, 1990). sox $R$ and sox $S$-encoded proteins are both essential for the induction of the sox $R$ regulon (Wu \& Weiss, 1991). Moreover, not only does the response of $E$. coli cells to $\mathrm{H}_{2} \mathrm{O}_{2}$ overlap with the superoxide response, but there is also overlap between the $\mathrm{H}_{2} \mathrm{O}_{2}$ and SOS (radiation repair) responses, and all three systems induce proteins common to the heat shock response (Farr \& Kogoma, 1991).

Reactive oxygen species have been implicated in many human diseases (Halliwell \& Gutteridge, 1989) and it is important that the response of eukaryotic cells to the various forms of oxidative stress be elucidated. Although several relevant genes for enzymes that may be involved in detoxifying oxidants have been cloned, the mechan- 
isms whereby eukaryotic cells co-ordinate their response to oxidants remains largely unexplored. Recent work in this laboratory (Collinson \& Dawes, 1992) has shown that an adaptive response to $\mathrm{H}_{2} \mathrm{O}_{2}$ can be induced in the yeast Saccharomyces cerevisiae in a manner similar to the inducibility of peroxide stress observed in bacteria. This response to $\mathrm{H}_{2} \mathrm{O}_{2}$ was induced by heat shock but $\mathrm{H}_{2} \mathrm{O}_{2}$ pretreatment did not confer thermotolerance.

This work has now been extended to investigate the response of $S$. cerevisiae to menadione (MD; 2-methyl1,4-naphthoquinone). When added extracellularly, MD generates superoxide radicals through a redox cycling mechanism (Hassan \& Fridovich, 1979) and is of interest since it is being tested in the treatment of arthritis and as an antitumour agent (Pitsillides et al., 1990; Nutter et al., 1991). Superoxides can be converted to $\mathrm{H}_{2} \mathrm{O}_{2}$ and subsequently to the hydroxyl radical $(\mathrm{OH} \cdot)$ through spontaneous disproportionation and enzymic reactions (Fridovich, 1983). According to Nutter et al. (1992), working with human MCF-7 cells, $\mathrm{H}_{2} \mathrm{O}_{2}$ and ultimately $\mathrm{OH}^{-}$are the main toxic species derived from MDgenerated superoxides. Greenberg \& Demple (1989) suggest that the response of $E$. coli to MD induces many of the proteins produced in response to $\mathrm{H}_{2} \mathrm{O}_{2}$ and also a further 33 proteins not seen with $\mathrm{H}_{2} \mathrm{O}_{2}$. Whilst Chaput \& Sels (1987) have studied damage caused by MD in the cell membrane of $S$. cerevisiae, inducibility of the oxidative response was not demonstrated.

This work examines whether $S$. cerevisiae has an inducible response to MD. Comparisons of the response to different types of stress help determine the specificity of the cellular response to certain agents. The possibility that a response to MD could overlap with those to $\mathrm{H}_{2} \mathrm{O}_{2}$ and heat-shock treatments was also considered.

\section{Methods}

Yeast strains. Strain BGW1-7a (MATa ade1-100 his4-519 leu2-2, 2-112 ura3-52) was supplied by Leonard Guarente (Massachusetts Institute of Technology, Cambridge, MA, USA); Petite strain Y3P (respiratory incompetent) was obtained from BGW1-7a using ethidium bromide treatment according to the method of Spencer \& Spencer (1988). Strain DBY747 (MAT $\alpha$ leu2-3, 2-112 his3-1 trp1-28 ura3-52) was available in the laboratory collection.

Dose response curve. Cells were grown overnight at $30^{\circ} \mathrm{C}$ with shaking in YEPD medium containing $2 \%(\mathrm{w} / \mathrm{v})$ glucose, $2 \%(\mathrm{w} / \mathrm{v})$ bactopeptone, $1 \%(\mathrm{w} / \mathrm{v})$ yeast extract. At an $\mathrm{OD}_{600}$ of 0.1 (representing approx. $1.8 \times 10^{6}$ viable cells $\mathrm{ml}^{-1}$ ), cells were harvested by centrifugation at $25^{\circ} \mathrm{C}(4000 \mathrm{~g}$ for $5 \mathrm{~min})$ and resuspended in $100 \mathrm{~mm}$ potassium phosphate buffer, $\mathrm{pH} 7 \cdot 4$. Samples $(5 \mathrm{ml})$ were treated with various concentrations of MD sodium bisulphite (Sigma) made up in $1 \mathrm{M}$ and $100 \mathrm{~mm}$ stock solutions. Aliquots $(100 \mu \mathrm{l})$ were taken at $15 \mathrm{~min}$ intervals over a period of $1 \mathrm{~h}$, diluted in $100 \mathrm{~mm}$-phosphate buffer $(\mathrm{pH} 7 \cdot 4)$ and plated on YEPD plates to obtain viable cell counts.

Adaptation or cross-resistance to oxidative stress. Cells were grown as described above and, after centrifugation, $5 \mathrm{ml}$ samples were re- suspended in fresh YEPD medium and received either no pretreatment (control) or pretreatment with (a) $0.2 \mathrm{mM}-\mathrm{MD},(b) 0.2 \mathrm{mM}-\mathrm{H}_{2} \mathrm{O}_{2},(c)$ cycloheximide $\left(50 \mu \mathrm{g} \mathrm{ml}^{-1}\right)$, or $(d)$ cycloheximide and $0.2 \mathrm{~mm}-\mathrm{MD}$. Cultures were then grown with shaking at $30^{\circ} \mathrm{C}$ for $1 \mathrm{~h}$, centrifuged and resuspended in $100 \mathrm{~mm}$-phosphate buffer, $\mathrm{pH} 7 \cdot 4$. Cells were then challenged with either $4 \mathrm{~mm}-\mathrm{MD}$ or $2 \mathrm{~mm}-\mathrm{H}_{2} \mathrm{O}_{2}$. Cell survival was monitored in the same way as described for the dose response curve.

Heat-shock treatment. Cultures were incubated overnight at $23^{\circ} \mathrm{C}$ with shaking. Cells were harvested, resuspended in fresh YEPD and incubated at either $(a) 23^{\circ} \mathrm{C}$ (control), (b) $23^{\circ} \mathrm{C}$ with $0.2 \mathrm{mM}-\mathrm{MD}$, or (c) $37^{\circ} \mathrm{C}$, for $1 \mathrm{~h}$ prior to being challenged with either $4 \mathrm{mM}-\mathrm{MD}$ or heat stress $\left(52^{\circ} \mathrm{C}\right)$. Samples were taken at $15 \mathrm{~min}$ intervals over $1 \mathrm{~h}$ for cells challenged with $4 \mathrm{mM}-\mathrm{MD}$ and at $2 \mathrm{~min}$ intervals over a period of 10 min for cells challenged with heat stress. Cell survival was determined by diluting samples in phosphate buffer before plating on YEPD medium.

$\mathrm{L}-\left[{ }^{35} S\right]$ Methionine labelling of proteins. Cultures were grown to an $\mathrm{OD}_{600} 0.1$ at $23^{\circ} \mathrm{C}$ in minimal glucose medium $\left[\mathrm{l}^{-1}: 20 \mathrm{~g}\right.$ glucose, $1.7 \mathrm{~g}$ Difco yeast nitrogen base (without amino acids and $\left.\left(\mathrm{NH}_{4}\right)_{2} \mathrm{SO}_{4}\right), 5 \mathrm{~g}$ $\left(\mathrm{NH}_{4}\right)_{2} \mathrm{SO}_{4}, 50 \mathrm{mg}$ auxotrophic requirements] supplemented with $30 \mathrm{mg}$ L-tyrosine $\mathrm{ml}^{-1}$ to increase methionine uptake. Cells were harvested, resuspended in fresh minimal glucose medium and $10 \mathrm{ml}$ samples were treated with either (a) no stress (control), (b) $0.2 \mathrm{mM}-\mathrm{MD},(c) 0.2 \mathrm{~mm}$ $\mathrm{H}_{2} \mathrm{O}_{2}$, or $(d)$ heat shock $\left(37^{\circ} \mathrm{C}\right)$. Samples were taken at 15 min intervals and pulse-labelled for $10 \mathrm{~min}$ with $30 \mu \mathrm{Ci}(1 \cdot 1 \mathrm{MBq}) \mathrm{L}-\left[{ }^{35} \mathrm{~S}\right]$ methionine (Trans ${ }^{35} \mathrm{~S}-\mathrm{Label}$, ICN Biochemicals). Labelling was terminated by addition of $100 \mu \mathrm{g}$ cycloheximide $\mathrm{ml}^{-1}$ and rapid cooling on ice. Cells were centrifuged and resuspended in $300 \mu \mathrm{l}$ SDS-lysis buffer $(0.0625 \mathrm{M}$ Tris $/ \mathrm{HCl}, \mathrm{pH} 6.8,5 \%$, v/v, 2-mercaptoethanol, $3 \%$, w/v, SDS, $4 \mathrm{~mm}$ -

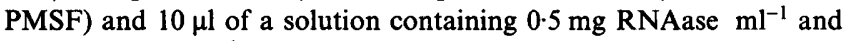
$1 \mathrm{mg}$ DNAase $\mathrm{ml}^{-1}$ was added. Approximately $0.3 \mathrm{~g}$ glass beads was added, tubes were vortexed for $2 \mathrm{~min}$ to disrupt the cells and proteins were heat-denatured $\left(100^{\circ} \mathrm{C}, 5 \mathrm{~min}\right)$. A $10 \mu \mathrm{l}$ aliquot of each sample was precipitated onto a glassfibre disc with $10 \%(\mathrm{w} / \mathrm{v})$ trichloroacetic acid (TCA) and incorporation of label was determined by scintillation counting. To standardize loading on gels, samples containing 30000 c.p.m. were made to $10 \%(\mathrm{v} / \mathrm{v})$ glycerol and $0.001 \%$ bromophenol blue and were separated by gel electrophoresis.

$S D S-P A G E$. Denatured protein samples were run at $30 \mathrm{~mA}$ for $270 \mathrm{~V} \mathrm{~h}$ at room temperature on a $10-15 \%(\mathrm{w} / \mathrm{v})$ gradient polyacrylamide-SDS slab gel made with the discontinuous buffer system of Laemmli (1970). Gels were stained with Coomassie blue to visualize protein standards, fixed overnight in $40 \%(\mathrm{v} / \mathrm{v})$ methanol/10\% (v/v) acetic acid solution, dried with a Bio-Rad gel dryer and autoradiographed using $\beta$-Max film (Amersham) at $-70^{\circ} \mathrm{C}$ for $6 \mathrm{~d}$.

\section{Results and Discussion}

Sensitivity of yeast cells to $M D$

Chaput \& Sels (1987) have shown that yeast cells are sensitive to $0.33 \mathrm{~mm}$-MD. To determine the degree of sensitivity of yeast strain BGW1-7a to MD, early exponential phase cells were harvested and exposed to concentrations of MD in the range 0.1-6 mM. Exponential phase was chosen since cells can become resistant to various forms of stress when they enter stationary phase (Schenberg-Frascino \& Moustacchi, 1972; Steels et al., 1991).

The dose response data (Fig. 1) indicated that cells of strain BGW1-7a were relatively resistant to $\mathrm{MD}$ at 


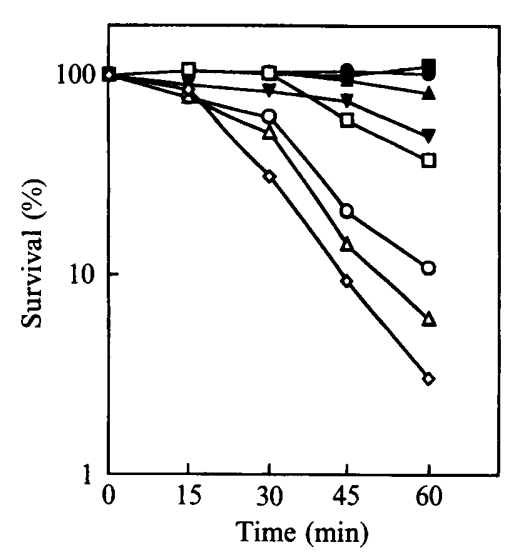

Fig. 1. Yeast cell (BGW1-7a) sensitivity to MD. Exponentially growing yeast cells $\left(30^{\circ} \mathrm{C}\right)$ were treated with various concentrations of MD for $60 \mathrm{~min}$. Samples were diluted and plated on YEPD solid media to monitor cell viability. MD concentrations were: $0.1(\mathbf{O}), 0.2(\mathbf{\Delta}), 0.5$ $(\nabla), 1(\square), 2(\bigcirc), 4(\triangle)$ and $6(\diamond) \mathrm{mm}$. $\square$, Control. Data are the mean of duplicates from a representative experiment.

concentrations below $1 \mathrm{~mm}$, but that at higher concentrations cell populations lost viability in an exponential manner.

\section{Adaptation of yeast cells to MD}

Yeast cells can adapt to stress induced by $\mathrm{H}_{2} \mathrm{O}_{2}$ treatment (Collinson \& Dawes, 1992). Since $\mathrm{MD}$ and $\mathrm{H}_{2} \mathrm{O}_{2}$ generate free radicals initially by different routes, and there are differences in the mechanisms whereby $E$. coli cells respond to free radical generating compounds and $\mathrm{H}_{2} \mathrm{O}_{2}$ (Greenberg \& Demple, 1989), it was important to determine if yeast, as a model eukaryote, could adapt to high concentrations of MD if previously exposed to low, non-lethal doses. From the data in Fig. 1, exposure to $0.2 \mathrm{~mm}-\mathrm{MD}$ for $1 \mathrm{~h}$ was chosen as a non-lethal pretreatment and $4 \mathrm{~mm}-\mathrm{MD}$ was used as a lethal concentration. Cells pretreated in glucose-containing medium (YEPD) and subsequently challenged with $4 \mathrm{~mm}$ MD in phosphate buffer showed increased survival compared to naive cells (Fig. 2). This demonstrates the existence of an adaptive response to MD in the yeast strain BGW1-7a. There are sometimes differences between yeast strains in their response to particular environmental stimuli. However, Fig. 2 shows that a comparable adaptive response to MD was obtained with a different strain (DBY747).

\section{Does the adaptive response to MD depend on mitochondrial function?}

Mitochondria are the sites of respiratory metabolism in eukaryotes and can affect the concentration of oxidants in the cell not only by acting as a compartment in which superoxides and hydroxyl radicals are generated, but

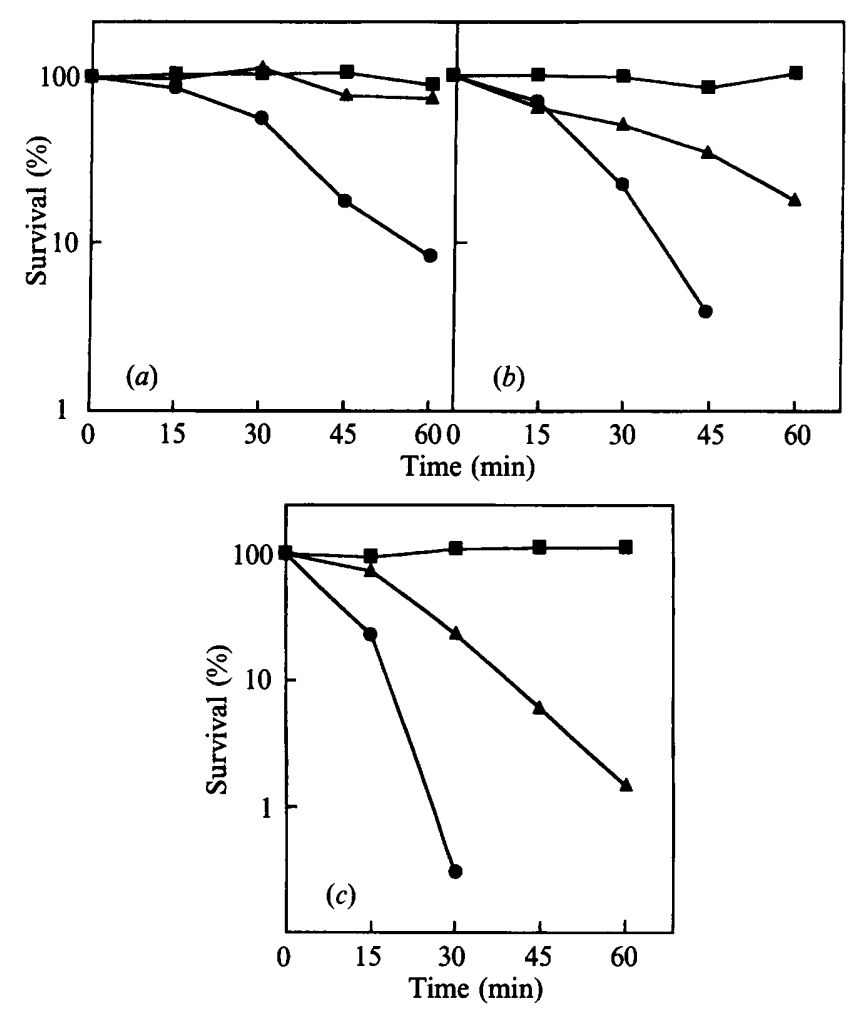

Fig. 2. Induction of MD tolerance in strains BGW1-7a (a), DBY747 (b) and a $\rho^{0}$ petite derivative of BGW1-7a $(c)$. Yeast cells were either pretreated with $0.2 \mathrm{mM}$-MD for $60 \mathrm{~min}$ in YEPD medium (non-lethal pretreatment) then challenged with $4 \mathrm{mM}-\mathrm{MD}$ in phosphate buffer to test for lethality $(\boldsymbol{\Delta})$, or exposed to $4 \mathrm{mM}-\mathrm{MD}$ without pretreatment (O). $\square$, Control. Note the increased sensitivity of the petite strain to MD necessitating a different scale in $(c)$. Samples were diluted and plated on YEPD to monitor cell viability. Data are the mean of duplicates from a representative experiment.

also due to the superoxide dismutase they contain. It is therefore possible that some mitochondrial functions are involved in the induction of the cellular response to MD. This was tested by determining whether an isogenic $\rho^{0}$ petite strain of BGW1-7a could still be induced by MD to protection against the oxidant. The petite strain was highly sensitive to MD but was still able to show an inducible response (Fig. 2c). This demonstrates that mitochondria do have some protective role against oxidants but shows that mitochondrial function is not required for inducibility, which is also the case for the inducible response observed using $\mathrm{H}_{2} \mathrm{O}_{2}$ (Collinson \& Dawes, 1992).

Does the adaptive response depend on de novo protein synthesis?

The adaptive response to MD could be due to either or both of two mechanisms. One possibility is that oxidation results in the modification of existing elements in the cell. This occurs in bacteria in the case of the $\operatorname{oxy} R$ protein. 


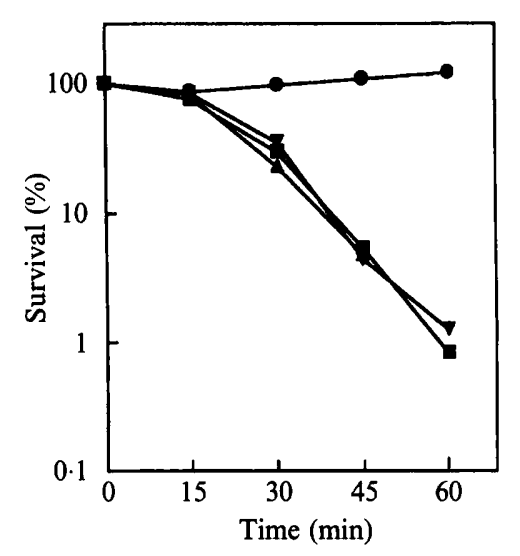

Fig. 3. The effect of cycloheximide on the acquisition of MD resistance. Yeast cells were pretreated with $50 \mu \mathrm{g}$ cycloheximide $\mathrm{ml}^{-1}$ and challenged with $4 \mathrm{~mm}-\mathrm{MD}(\Delta)$, pretreated with $50 \mu \mathrm{g}$ cycloheximide $\mathrm{ml}^{-1}$ and $0.2 \mathrm{mM}-\mathrm{MD}$ and challenged with $4 \mathrm{mM}-\mathrm{MD}(\boldsymbol{\nabla})$, pretreated with $50 \mu \mathrm{g}$ cycloheximide $\mathrm{ml}^{-1}$ without further treatment $(\circlearrowleft)$, or treated with $4 \mathrm{~mm}-\mathrm{MD}$ without pretreatment (西). Samples were diluted and plated on YEPD to monitor cell viability. Data are the mean of duplicates from a representative experiment.

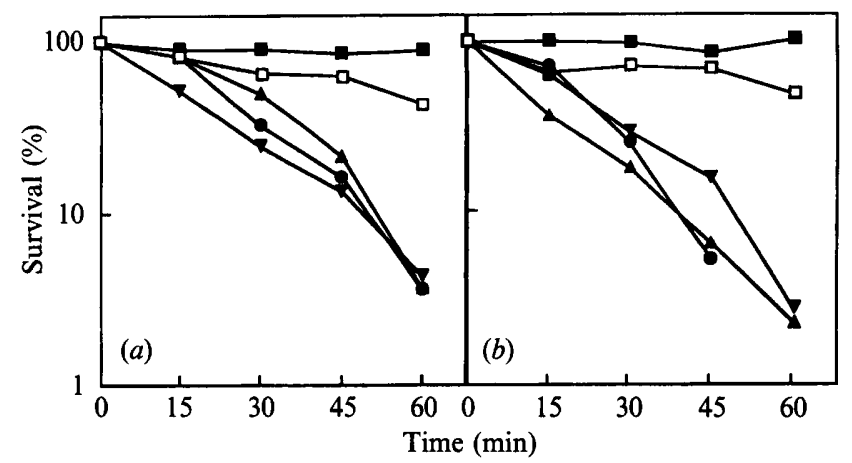

Fig. 4. Cross resistance between $\mathrm{MD}$ and $\mathrm{H}_{2} \mathrm{O}_{2}$ in strain BGW1-7a (a) and DBY747 (b). Cells were either exposed to $4 \mathrm{mM}$-MD without pretreatment ( $), 2 \mathrm{mM}-\mathrm{H}_{2} \mathrm{O}_{2}$ without pretreatment $(\boldsymbol{\Delta})$, pretreatment with $0.2 \mathrm{mM}-\mathrm{MD}$ and subsequent exposure to $2 \mathrm{mM}-\mathrm{H}_{2} \mathrm{O}_{2}(\boldsymbol{\nabla})$, or pretreatment with $0.2 \mathrm{mM}-\mathrm{H}_{2} \mathrm{O}_{2}$ and subsequent exposure to $4 \mathrm{mM}-\mathrm{MD}$ (口). $\square$, Control. Samples were diluted and plated on YEPD to monitor cell viability. Data are the mean of duplicates from a representative experiment.

Both reduced and oxidized forms of this regulatory protein bind to the promoter but only the oxidized form activates transcription (Storz et al., 1990). This may be due to a distinct conformational change that takes place upon oxidation of the protein. Cells can also adapt to stress by inducing the synthesis of new proteins. An example in bacteria is the transcriptional activation of peroxide-stress-related genes by the $\operatorname{oxy} R$ regulatory protein (Christman et al., 1985).

It has been shown previously that $50 \mu \mathrm{g}$ cycloheximide $\mathrm{ml}^{-1}$ inhibits protein synthesis in strain BGW1-7a (Collinson \& Dawes, 1992). Pretreatment with this level of cycloheximide and $0.2 \mathrm{mM}-\mathrm{MD}$ completely prevented

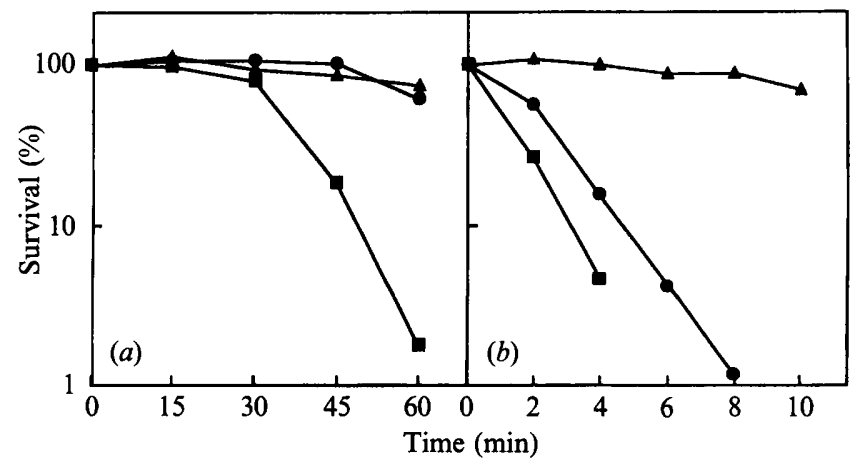

Fig. 5. Cross-resistance between MD and heat shock. BGW1-7a cells grown at $23{ }^{\circ} \mathrm{C}$ were exposed to $37^{\circ} \mathrm{C}$ heat shock for $60 \mathrm{~min}(\boldsymbol{A})$ or pretreated with $0.2 \mathrm{mM}-\mathrm{MD}(\Theta)$ and challenged $(a)$ with $4 \mathrm{mM}-\mathrm{MD}$ or (b) by incubation at $49^{\circ} \mathrm{C}$. $\mathrm{D}$, No pretreatment. Samples were diluted and plated on YEPD to monitor cell viability. Data are the mean of duplicates from a representative experiment.

the acquisition of MD resistance (Fig. 3). Therefore the adaptive response seen in Fig. 2 is inducible. In the control experiment cells were pretreated with cycloheximide only and subsequently challenged with $4 \mathrm{mM}-$ MD. These cells were killed at a similar rate to that observed without pretreatment (Fig. 3). This differs to some extent from the effect seen with $\mathrm{H}_{2} \mathrm{O}_{2}$ in which cycloheximide pretreatment afforded some protection against challenge with $2 \mathrm{~mm}-\mathrm{H}_{2} \mathrm{O}_{2}$ (Collinson \& Dawes, 1992).

Therefore, de novo protein synthesis is an absolute requirement for the adaptive response to $\mathrm{MD}$ in yeast cells. This contrasts with their adaptation to $\mathrm{H}_{2} \mathrm{O}_{2}$ in which protein synthesis appears to be required for only some of the adaptation. These results indicated that in yeast there are differences between the way cells respond to free radical stress generated by $M D$ and to peroxide stress.

\section{Cross-resistance to $\mathrm{H}_{2} \mathrm{O}_{2}$}

Given that superoxides can easily be converted to $\mathrm{H}_{2} \mathrm{O}_{2}$ and $\mathrm{OH} \cdot$, and that $\mathrm{H}_{2} \mathrm{O}_{2}$ has been proposed as the main toxic species of MD-induced stress in human cells (Nutter et al., 1992), MD may command a wider response than $\mathrm{H}_{2} \mathrm{O}_{2}$, and one which might encompass the $\mathrm{H}_{2} \mathrm{O}_{2}$ adaptive response. To assess the extent of cross-protection between superoxide and peroxide stresses, cells were pretreated with low concentrations of $\mathrm{H}_{2} \mathrm{O}_{2}$ and subsequently exposed to high concentrations of $\mathrm{MD}$ and vice versa. Cells pretreated with $\mathrm{H}_{2} \mathrm{O}_{2}$ were protected against MD (Fig. 4) which is consistent with the view that MD generates the same toxic species as $\mathrm{H}_{2} \mathrm{O}_{2}$ (Nutter et al., 1992). However, pretreatment with MD did not protect cells against $\mathrm{H}_{2} \mathrm{O}_{2}$ (Fig. 4). Therefore, it appears that the $\mathrm{H}_{2} \mathrm{O}_{2}$ stress response is induced very 


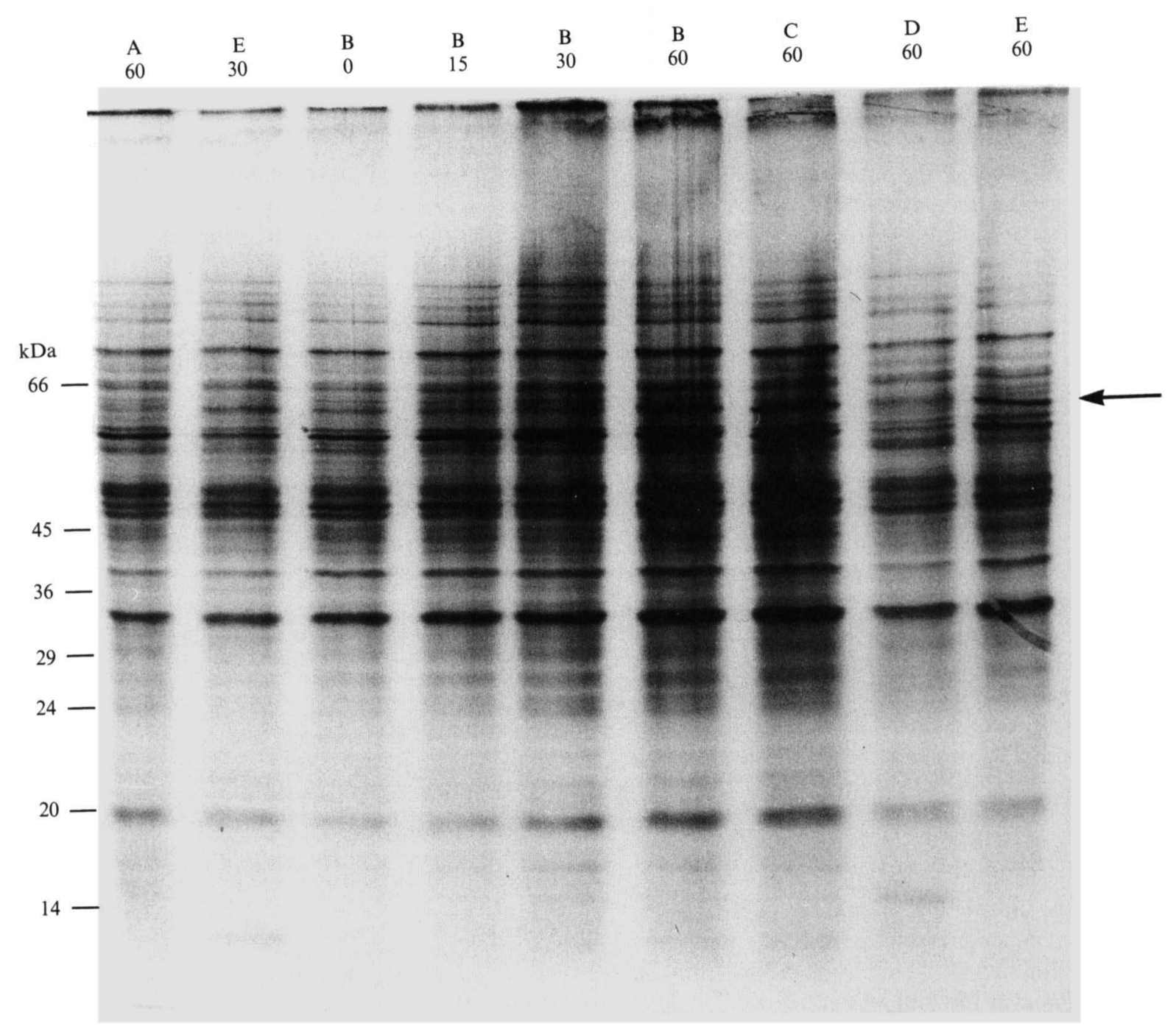

Fig. 6. Polypeptides synthesized during MD, peroxide and heat shock adaptation. Yeast cells were grown in glucose minimal medium supplemented with $30 \mathrm{mg}$ L-tyrosine $\mathrm{l}^{-1}$. At the times indicated $(\mathrm{min})$ cultures were pulse-labelled $(10 \mathrm{~min})$ with $30 \mu \mathrm{Ci}(1 \cdot 1 \mathrm{MBq})$ of L- $\left[{ }^{35} \mathrm{~S}\right]$ methionine. Conditions used were: (A) no treatment (control), (B) $0.2 \mathrm{mM}-\mathrm{MD},(\mathrm{C}) 0.4 \mathrm{mM}-\mathrm{MD},(\mathrm{D}) 0.2 \mathrm{mM}-\mathrm{H}_{2} \mathrm{O}_{2}$ and (E) heat shock $\left(37^{\circ} \mathrm{C}\right)$. The MD-induced protein is indicated by an arrow. Protein standards used were bovine milk $\alpha$-lactalbumin (14 kDa), soybean trypsin inhibitor $(20 \mathrm{kDa})$, PMSF-treated bovine pancreas trypsinogen $(24 \mathrm{kDa})$, bovine erythrocyte carbonic anhydrase $(29 \mathrm{kDa})$, rabbit muscle glyceraldehyde-3-phosphate dehydrogenase $(36 \mathrm{kDa})$, egg albumin $(45 \mathrm{kDa})$ and bovine albumin $(66 \mathrm{kDa})$.

little, if at all, by MD under the conditions used in these experiments. This points to a difference in the response of bacteria and yeast to MD given the extent to which MD induces proteins that are also induced by $\mathrm{H}_{2} \mathrm{O}_{2}$ in bacteria (Greenberg \& Demple, 1989). Results with yeast strain DBY747 confirmed that this phenomenon was not strain-specific (Fig. 4), raising questions regarding the mechanisms whereby MD induces protection and how it kills yeast cells.

The explanation of these results may lie in the difference between the nature of the protective response induced by each oxidant rather than in the reactive species responsible for cell damage. Since $\mathrm{H}_{2} \mathrm{O}_{2}$ pre- treatment protects against $\mathrm{MD}$, then $\mathrm{H}_{2} \mathrm{O}_{2}$ may act to induce detoxification of species that are produced by both oxidants. In contrast, MD induces a different system which could act at an early stage in free radical generation or which could exclude, eliminate or inactivate $\mathrm{MD}$, or reduce its ability to generate free radicals without affecting the toxicity of $\mathrm{H}_{2} \mathrm{O}_{2}$.

\section{Cross-resistance to heat stress}

It has been proposed that some proteins induced during heat shock may act as general anti-stress proteins. In $E$. coli, for example, the heat shock proteins GroES and 
GroEL are involved in peroxide and superoxide stress as well as starvation and the SOS response (Farr \& Kogoma, 1991). Privalle \& Fridovich (1987) have shown that superoxide dismutase (MnSOD) is induced under heat shock conditions, and suggest superoxide anions may be generated when the electron transport system in the membrane is affected by heat. Overexpression of oxy $R$ in a Sal. typhimurium mutant confers resistance to killing by heat, possibly due to the constitutive overexpression of heat shock proteins (Christman et al., 1985).

Although prior heat shock protected yeast strain BGW1-7a against $\mathrm{H}_{2} \mathrm{O}_{2}$, pretreatment with $\mathrm{H}_{2} \mathrm{O}_{2}$ did not confer thermotolerance (Collinson \& Dawes, 1992). This result differs from observations by Christman et al. (1985) in Sal. typhimurium, indicating that there may be substantial differences between prokaryotes and eukaryotes in their coordination of different shock responses. It was important therefore to test for cross-protection in yeast between MD-induced stress and heat stress.

Whereas heat shock protected cells from the lethal effects of high concentrations of MD, pretreatment with MD conferred little, if any, thermotolerance (Fig. 5). This suggests that the heat shock response is a broad, general anti-stress response, whilst the induction of responses to peroxide or superoxide stress are more specific.

\section{Proteins induced during $\mathrm{MD}, \mathrm{H}_{2} \mathrm{O}_{2}$ and heat stress}

The overlap in the inducible responses to different forms of stress observed in bacteria and to some extent in yeast, raises the question as to which sets of proteins are induced in common in the different systems.

To assess whether there were any similarities between the proteins induced by MD and those induced by $\mathrm{H}_{2} \mathrm{O}_{2}$ and heat shock (Collinson \& Dawes, 1992), cultures were grown at $23{ }^{\circ} \mathrm{C}$ overnight in glucose minimal medium, harvested and resuspended in fresh medium. These cells were exposed to either no stress, $0.2 \mathrm{mM}-\mathrm{MD}, 0.2 \mathrm{~mm}$ $\mathrm{H}_{2} \mathrm{O}_{2}$ or heat shock at $37^{\circ} \mathrm{C}$, and pulse-labelled at $15 \mathrm{~min}$ intervals with $\mathrm{L}-\left[{ }^{35} \mathrm{~S}\right]$ methionine for $10 \mathrm{~min}$. One-dimensional gel electrophoresis (Fig. 6) showed an increase in only one polypeptide (molecular mass $60 \mathrm{kDa}$ ) upon MD treatment compared with a control culture. A polypeptide of this size did appear in response to heat shock treatment; however, both $\mathrm{H}_{2} \mathrm{O}_{2}$ and heat-shock led to the appearance of at least 10 polypeptides as seen previously (Collinson \& Dawes, 1992). It is clear, even within the limitations of one-dimensional electrophoresis, that induction by MD presents a unique response to oxidative stress. This differs from the situation in bacteria.

The work outlined indicates that $S$. cerevisiae is sensitive to $\mathrm{MD}$ and can mount an inducible response against this redox cycling compound. Unlike the $\mathrm{H}_{2} \mathrm{O}_{2}$ inducible response, however, there is an absolute requirement for de novo protein synthesis. Mitochondrial function is not required for either the MD- or the $\mathrm{H}_{2} \mathrm{O}_{2}$ induced response.

Increased survival of cells pretreated with $\mathrm{H}_{2} \mathrm{O}_{2}$ and subsequently challenged with a high concentration of MD is consistent with the proposal that $\mathrm{H}_{2} \mathrm{O}_{2}$ and consequently the $\mathrm{OH} \cdot$ radical are mainly responsible for cell damage by MD. However, MD does not induce a response which protects against $\mathrm{H}_{2} \mathrm{O}_{2}$, indicating a fundamental difference in the cellular responses to these reactive oxygen species.

Results presented here indicate that further investigation is warranted into the genetic mechanism governing the induction of the response of eukaryotes to specific oxidants and other forms of stress. The yeast $S$. cerevisiae presents many advantages as an organism to study these systems in detail.

This work was supported by a grant from the Australian Research Council.

\section{References}

ANDrew, P. W., JACKeTt, P. S. \& Lowrie, D. B. (1985). Killing and degradation of microorganisms by macrophages. In Mononuclear Phagocytes: Physiology and Pathology, pp. 311-335. Edited by R. T. Dean \& W. Jessup. Amsterdam: Elsevier.

Chaput, M. \& Sels, A. (1987). Sensitivity of yeast cells to reactive oxygen species generated in the extracellular space. Biochimie 69, $53-62$.

Christman, M. F., Morgan, R. W., Jacobson, F. S. \& Ames, B. N. (1985). Positive control of a regulon for defenses against oxidative stress and some heat-shock proteins in Salmonella typhimurium. Cell 41, 753-762.

Collinson, L. P. \& Dawes, I. W. (1992). Inducibility of the response of yeast cells to peroxide stress. Journal of General Microbiology 138, 329-335.

Dean, R. \& Simpson, J. (1989). Free radicals: the good, the bad... Today's Life Science 1, 28-34.

DEMPLE, B. \& HaLbrooK, J. (1983). Inducible repair of oxidative DNA damage in Escherichia coli. Nature, London 304, 466-468.

FARR, S. B. \& Kogoma, T. (1991). Oxidative stress responses in Escherichia coli and Salmonella typhimurium. Microbiological Reviews 55, 561-585.

FrIDOVICH, I. (1983). Superoxide radical: an endogenous radical. Annual Review of Pharmacology and Toxicology 23, 239-257.

GREENBERG, J. T. \& DEMPLE, B. (1989). A global response induced in Escherichia coli by redox-cycling agents overlaps with that induced by peroxide stress. Journal of Bacteriology 171, 3933-3939.

Halliwell, B. \& GuTteridge, J. M. C. (1989). Free Radicals in Biology and Medicine, pp. 161-164. 2nd edn. Oxford: Clarendon.

Hassan, H. M. \& Fridovich, I. (1979) Intracellular production of superoxide radical and of hydrogen peroxide by redox active compounds. Archives of Biochemistry and Biophysics 196, 385-395.

LAEMmLI, U. K. (1970). Cleavage of structural proteins during the assembly of the head of bacteriophage T4. Nature, London 227, 680-685.

NutTer, L. M., Cheng, A.-L., Hung, H.-L., Hsieh, R.-K., NGo, E. O. \& LIU, T.-W. (1991). Menadione: spectrum of anticancer activity and effects on nucleotide metabolism in human neoplastic cell lines. Biochemical Pharmacology 41, 1283-1292. 
NutTer, L. M., NGo, E. O., FisheR, G. R. \& GutierReZ, P. L. (1992). DNA strand scission and free radical production in menadionetreated cells. Journal of Biological Chemistry 267, 2474-2479.

PhiLliPs, J. P. \& HillikeR, A. J. (1990). Genetic analysis of oxygen defense mechanisms in Drosophila melanogaster. Advances in Genetics 28, 43-64.

Pitsillides, A. A., Blake, S. M., Glynn, L. E., Bitensky, L. \& CHAYEN, J. (1990). Amelioration by menadione of the experimental chronic immune arthritis in the rabbit. Cell Biochemistry and Function 8, 221-226.

Privalle, C. T. \& Fridovich, I. (1987). Induction of superoxide dismutase in Escherichia coli by heat shock. Proceedings of the National Academy of Sciences of the United States of America 84, 2723-2726.

SCANDALIOS, J. G. (1990). Response of plant antioxidant defense genes. Advances in Genetics 28, 2-35.

SCHENBERG-Frascino, A. \& Moustacchi, E. (1972). Lethal and mutagenic effects of elevated temperature on haploid yeast. Molecular and General Genetics 115, 243-257.
SPENCER, J. F. T. \& SPENCER, D. M. (1988). Yeast Genetics. In Yeast: a Practical Approach, pp. 65-106. Edited by I. Campbell \& J. H. Duffus. Oxford \& Washington: IRL Press.

Steels, E. L., Learmonth, R. P. \& Watson, K. (1991). Heat and oxidative stress as a function of membrane lipid composition in yeast. Proceedings of the Australian Society for Biochemistry and Molecular Biology 23, C46.

Storz, G., Christman, M. F., Sies, H. \& Ames, B. N. (1987). Spontaneous mutagenesis and oxidative damage to DNA in Salmonella typhimurium. Proceedings of the National Academy of Sciences of the United States of America 84, 8917-8921.

Storz, G., TARTaglia, L. A. \& Ames, B. N. (1990). Transcriptional regulator of oxidative stress-inducible genes: direct activation by oxidation. Science 248, 189-194.

TsaneVA, I. R. \& Weiss, B. (1990). soxR, a locus governing a superoxide response regulon in Escherichia coli K-12. Journal of Bacteriology 172, 4197-4205.

WU, J. \& WeIss, B. (1991). Two divergently transcribed genes, sox $R$ and soxS, control a superoxide response regulon in Escherichia coli. Journal of Bacteriology 173, 2864-2871. 